\title{
Sistem Informasi Belajar Mengajar di SMA N Mojogedang Berbasis Android
}

\author{
Anton Respati Pamungkas*1, Djayus Nor Salim ${ }^{2}$, Intan Rahmawati ${ }^{3}$ \\ 1,2,3 Program Studi Sistem Informasi, STMIK AUB, Surakarta, Indonesia \\ e-mail: *1anton18@stmik-aub.ac.id, ${ }^{2}$ djayus.nur@stmik-aub.ac.id, \\ 32167100849@student.stmik-aub.ac.id
}

\begin{abstract}
Abstrak
Dalam penelitian ini, sistem yang akan dibangun merupakan aplikasi yang berbasis Android. Pembutan aplikasi menggunakan software Andoid Studio dengan bahasa pemrograman Java, dan PHP serta MySQL untuk pengolahan basis data. Untuk pengembangan sistem digunakan metode waterfall, sedangkan untuk analis sistem menggunakan analisis PIECES. Pengujian aplikasi menggunakan metode blackbox untuk selanjutnya dilakukan pemeliharaan secara berkala. Aplikasi Sistem Informasi digunakan sebagai media penyebaran informasi dan komunikasi antara pihak sekolah dengan siswanya yang dapat diakses kapan saja dan dimana saja. Aplikasi memiliki beberapa fitur seperti profil sekolah, fasilitas sekolah, jadwal pelajaran, jadwal ekstrakulikuler, agenda sekolah, berita sekolah, materi pelajaran, bank soal, tugas, nilai, hingga forum. Sehingga dengan adanya aplikasi sistem informasi ini mampu meningkatkan pelayanan dan penyebaran informasi di SMA N Mojogedang menjadi lebih efektif dan efisien.
\end{abstract}

Kata kunci-Android, Android Studio, Sistem Informasi, Sekolah

\section{Abstract}

The system to be built is an Android-based application. In this research application made by Android Studio software with the Java programming language, and PHP and MySQL for database processing. System development, the waterfall method is used, while for systems analysts using PIECES analysis. For application testing use the blackbox method for subsequent maintenance periodically. The Information System application is used as a media for disseminating information and communication between the school and its students which can be accessed anytime and anywhere. The application has several features such as school profiles, school facilities, timetable, extracurricular schedules, school agendas, school news, subject matter, question bank, task, grades, to forums. So that this information system application can improve services and delivery information at Mojogedang's senior high school to be more effectively and efficiently.

Keywords-Android, Android Studio, Information System, School

\section{PENDAHULUAN}

Perkembangan teknologi saat ini sangat berpengaruh terhadap kehidupan sehari-hari, dan kebutuhan informasi yang tepat, cepat dan praktis sangat dibutuhkan untuk menunjang kegiatan masyarakat. Hadirnya smartphone sangat membantu manusia dalam mempermudah segala aktivitas, ini semua tidak terlepas dengan kecanggihan smartphone yang di dalamnya terdapat sistem operasi android. Sistem operasi android merupakan sistem yang bersifat open 
source yang dikembangkan oleh Google. Smartphone berbasis android tidak hanya digunakan sebagai hiburan semata tetapi juga digunakan sebagai media yang dapat memudahkan dan membantu manusia untuk mendapatkan informasi yang dibutuhkan kapanpun dan dimanapun.

Saat ini sekolah belum menerapkan teknologi untuk operasionalnya, terutama dimasa pandemi ini, maka sekarang sekolah bergantung pada teknologi untuk operasionalnya. Sistem informasi pada sekolah merupakan suatu yang sangat penting bagi guru dan siswa. sistem informasi dapat digunakan untuk melihat profil tentang sekolah, fasilitas, berita sekolah, agenda, data guru, data siswa, kurikulum, jadwal pelajaran, jadwal mengajar guru,dan jadwal ekstrakurikuler, menampilkan materi pelajaran, tugas,kuis dan bank soal, penilaian masingmasing mata pelajaran, data nilai siswa, dan hasil nilai siswa. Dengan adanya aplikasi sistem informasi siswa dapat mudah mengakses sistem informasi melalui perangkat smartphone android yang selama ini masih dilakukan dengan cara manual. Dengan aplikasi sistem informasi berbasis android ini, siswa bisa dengan mudah mendapatkan informasi yang dibutuhkan, dalam aktivitas sekolah kapanpun dan dimanapun selama masih terhubung dengan jaringan internet.

Sekolah sebagai suatu instansi pemerintah di bidang pendidikan membutuhkan banyak melakukan pengolahan data yaitu data administrasi, siswa maupun guru. Pengguna informasi di sekolah meliputi pengguna seperti siswa dan guru serta orang-orang yang terlibat dalam pembelajaran. Sekolah diharapkan dapat menyediakan informasi yang berkualitas. informasi tergantung pada tiga hal yaitu informasi harus akurat, tepat pada waktunya, dan relevan.

Sistem informasi sekolah berbasis android merupakan salah satu media dalam mencari informasi tentang SMA N Mojogedang. akan menjadi tidak efisien jika setiap kali ingin melihat informasi baru harus menunggu pengumuman agar memudahkan siswa dan guru untuk mencari informasi tentang SMA N Mojogedang, maka penelitian ini mengambil judul "Sistem Informasi Belajar Mangajar di SMA N Mojogedang Berbasis Android".

\section{METODE PENELITIAN}

\subsection{Metode Analisa Sistem PIECES}

Untuk mengindentifikasi masalah, maka harus dilakukan Analisis PIECES (Performance, Information, Economy, Control, Efeciency, dan Service) [2]. Adapun pengertian dari analisis pieces sebagai berikut:

a. Analisis Kinerja (performance)

Masalah Kinerja terjadi ketika tugas-tugas yang dijalankan oleh sistem mencapai sasaran. Kinerja diukur dengan jumlah produksi dan waktu tanggap. Jumlah produksi adalah jumlah pekerjaan yang dilaksanakan selama jangka waktu tertentu. Waktu tanggap adalah keterlambatan rata-rata antara suatu transaksi dengan tanggapan yang diberikan kepada transaksi tersebut.

b. Analisis Informasi (information)

Informasi merupakan komoditas yang penting bagi pemakai akhir. Karena Informasi yang akan dihasilkan dapat memenuhi keinginan dari pengguna dan juga dapat mengatasi masalahmasalah yang ada. Informasi yang ada ini pun dapat dimanfaatkan oleh pihak internal atau pihak external.

c. Analisis ekonomi (economy)

Ekonomi merupakan motivasi paling umum bagi suatu lembaga. Pijakan dasar bagi kebanyakan manajer adalah biaya yang murah.

d. Analisis Pengendalian (control)

Tugas-tugas dari sustu sistem informasi perlu di monitor dan dibetulkan jika ditemukan adanya kinerja yang di bawah standar. Kontrol dipasang untuk meningkatkan kinerja sistem, mencegah atau mendeteksi penyalahgunaan atau kesalahan sistem dan menjamin keamanan data.

GO INFOTECH: JURNAL ILMIAH STMIK AUB Vol. 27, No. 1, Juni 2021: 71-84 
e. Analisis efisiensi (efficiency)

Efisiensi berhubungan dengan bagaimana sumber tersebut digunakan dengan pemborosan yang minimal. Oleh karena itu, masalah efisiensi membutuhkan peningkatan output/hasil. Karena sistem yang ada telah dapat di daya gunakan dengan baik dan juga telah dapat menghasilkan output seusai dengan yang diharapkan.

f. Analisis Pelayanan (service)

Pelayanan yang baik dapat mencerminkan suatu lembaga itu baik atau tidak baik, sehingga pelayanan harus juga diperhitungkan secara baik.

\subsection{Wawancara}

Wawancara digunakan sebagai teknik pengumpulan data apabila peneliti ingin melakukan studi pendahuluan untuk menemukan permasalahan yang harus diteliti, tetapi juga apabila peneliti ingin mengetahui hal-hal dari responden yang lebih mendalam [31].

Penulis melakukan wawancara dengan guru dan siswa SMA N Mojogedang, Profil SMA N Mojogedang, bagaimana proses informasi di SMA N Mojogedang, bagaimana proses belajar mengajar di SMA N Mojogedang.

\subsection{Observasi}

Dalam observasi peneliti terlibat dengan kegiatan sehari-hari orang yang sedang diamati atau yang digunakan sebagai sumber data penelitian [31].

Penulis melakukan observasi dengan mengamati secara langsung proses pencetakan informasi, proses belajar mengajar di SMA N Mojogedang.

\subsection{Metode Pustaka}

Studi kepustakaan berkaitan dengan kajian teoritis dan referensi lain yang terkait dengan nilai, budaya, dan norma yang berkembang pada situasi sosial yang diteliti. Dan ada tiga kriteria yang terkait teori yang digunakan sebagai landasan penelitian, yaitu relevansi, kemutakhiran dan keaslian [31].

Penulis mencari informasi dari internet, dari perpustakaan, dari buku dan jurnal sebagai bahan referensi sebagai acuan dalam penulisan laporan dan juga pembuatan software aplikasi ini.

\subsection{Usecase Diagram}

Usecase mendiskripsikan sebuah interaksi antara lebih aktor dengan sistem informasi yang akan dibuat. Sistem informasi belajar mengajar di SMA N Mojogedang akan dibahas dalam use case yaitu mengenai aksi antar aktor yang meliputi guru, siswa dan admin. Untuk lebih jelasnya seperti Gambar 1 berikut. 


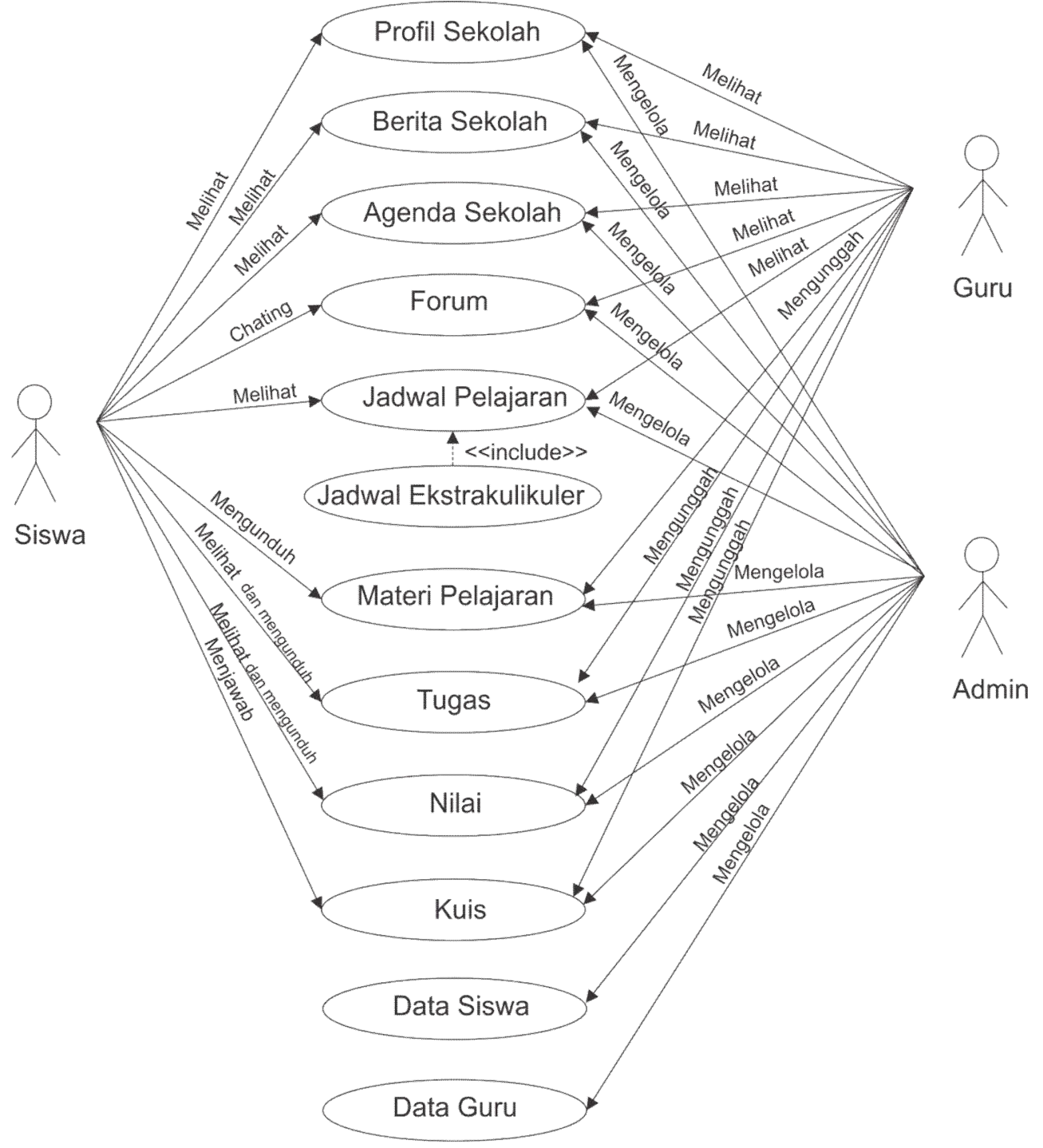

Gambar 1. Usecase Diagram

\section{HASIL DAN PEMBAHASAN}

\subsection{Analisis Sistem}

Untuk menganalisa kelemahan sistem diperlukan langkah untuk mengidentifikasi dan memberikan solusi terhadap kelemahan sistem yang ada, maka sebagai landasan penulis menggunakan metode atau kerangka PIECES yang terdiri dari performance, information, economy, control, efficiency dan service. Analisa ini digunakan sebagai alat ukur untuk menentukan sistem baru layak atau tidak, karena enam aspek ini harus mengalami peningkatan ukuran yang lebih baik dari sistem lama agar dapat mendukung proses transaksi.

a. Analisa Kinerja Sistem (Performance)

Proses pemberitahuan informasi di SMA N Mojogedang disampaikan secara konvensional, dimana masih menggunakan papan pengumuman. Sehingga pesan yang disampaikan terbatas. Selain itu, terkadang ada siswa yang tidak paham dengan infomasi tersebut, sehingga siswa harus menuju ke kantor untuk menanyakan lebih detail mengenai informasi tersebut.

b. Analisa Informasi (information) 
Informasi merupakan data yang telah diolah menjadi bentuk yang lebih berarti dan berguna bagi penerimanya. Informasi yang disampaikan pada papan pengumuman sangat terbatas pada besarnya papan, belum lagi jika informasi penting tersebut tertutup oleh informasi yang lain. Sedangkan dalam sistem belajar mengajar di SMA N Mojogedang, informasi yang disampaikan berupa materi pelajaran yang hanya dijelaskan secara singkat oleh guru dengan waktu yang terbatas.

c. Analisis Ekonomi (Economy)

Dari segi ekonomi, pihak sekolah harus menyediakan kertas untuk mencetak informasi yang diberikan, sehingga menambah anggaran untuk pengeluaran tinta, kertas dan double tape. Belum lagi informasi yang disuguhkan tergolong menghabiskan banyak kertas seperti halnya informasi hasil ujian.

d. Analisis Pengendalian (Control)

Analisa pengendalian adalah tahapan analisa yang bertujuan untuk mencegah, mendeteksi penyalahgunaan maupun kesalahan sistem, serta menjamin keamanan data dan informasi. Ketika informasi ditempelkan pada papan pengumuman, informasi akan rentan dicoret maupun hilang.

e. Analisis Efisiensi (Efficiency)

Analisa efesiensi adalah peningkatan terhadap efesiensi operasional, Sistem dikatakan efisien atau berhasil, jika dapat menjadi sasaran yang diinginkan dan tidak mengeluarkan banyak waktu dan tenaga kerja. Informasi yang disampaiakan seperti jadwal pelajaran, jadwal ujian, nilai dirasa kurang efektif jika mengandalkan papan pengumuman.

f. Analisis Pelayanan (Service)

Dalam hal pelayanan yang berkaitan dengan pemberian informasi mengenai nilai, jadwal pelajaran, jadwal ekstrakulikuler, dan berita mengenai sekolah masih mengandalkan papan pengumuman yang dinilai tidak konservatif.

\subsection{Implementasi Interface Program}

Dalam pembuatan sistem informasi belajar mengajar di SMA N Mojogedang ini dibutuhkan suatu implementasi untuk menguraikan program dan analisis dari hasil program yang telah dibuat. Tujuan pembahasan ini adalah untuk memberi petunjuk cara menggunakan program untuk admin melalui web Gambar 2 dan program untuk user melalui aplikasi android.

a. Halaman login Admin

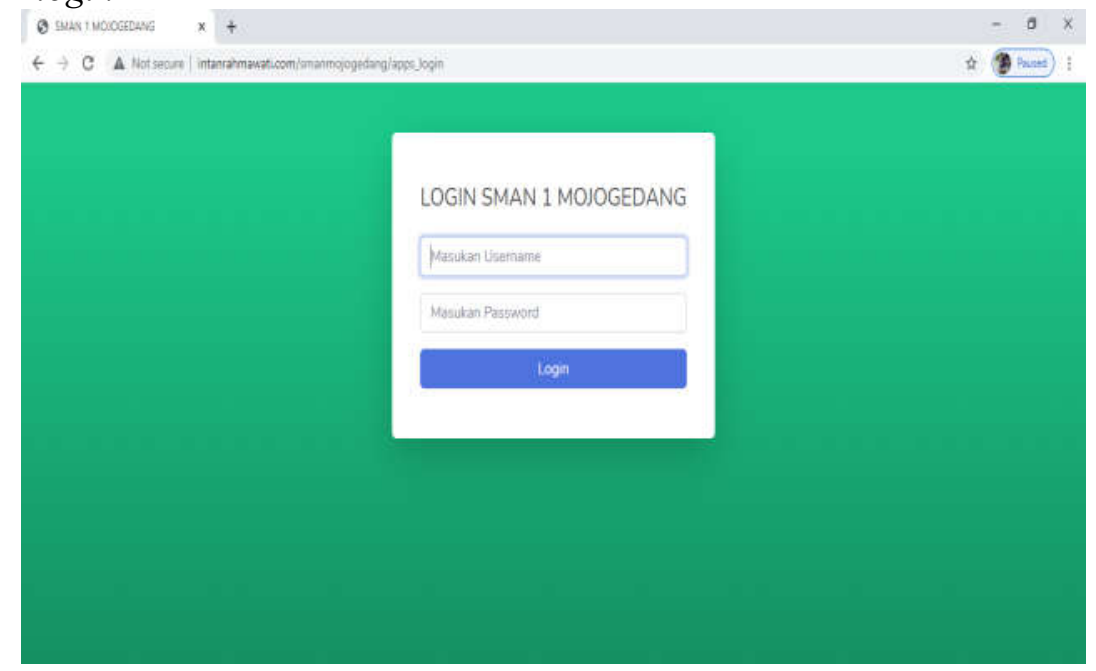

Gambar 2. Halaman login admin 
Keterangan halaman Gambar 1 digunakan untuk login kedalam sistem admin, dengan menggunakan username, password yang sudah terdaftar sebelumnya.

b. Halaman Dashboard

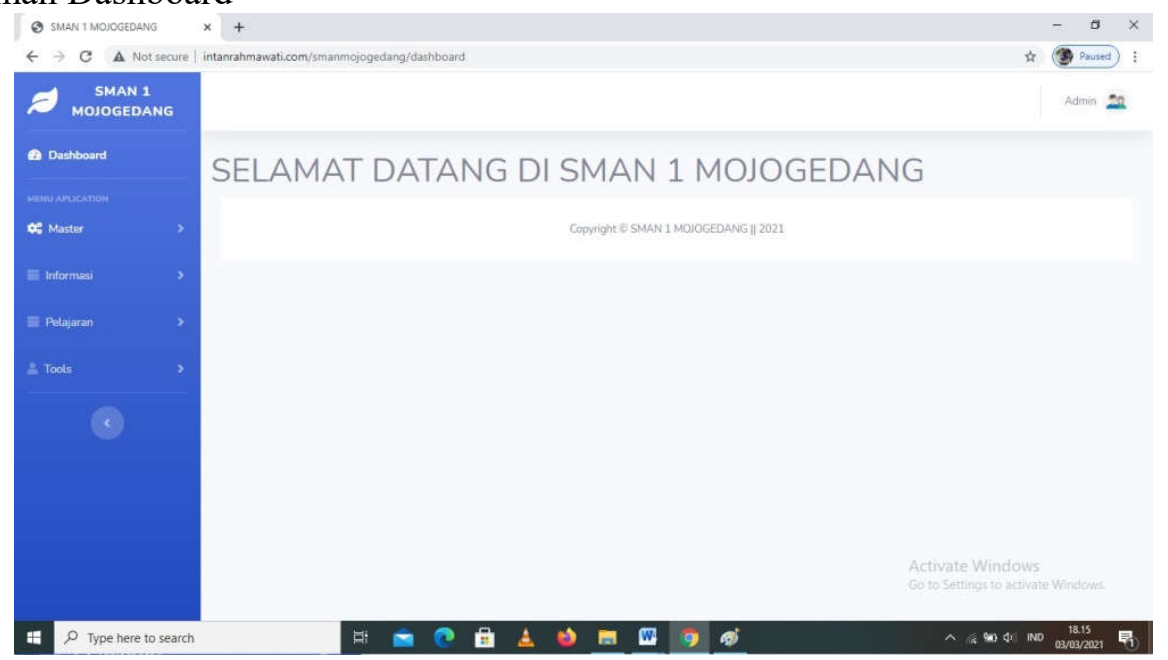

Gambar 2. Halaman dashboard

Keterangan halaman Gambar 2 merupakan halaman utama dari halaman admin, dimana pada tampilan utamanya terdapat headline Selamat Datang di SMA N Mojogedang.

c. Halaman Master Mata Pelajaran

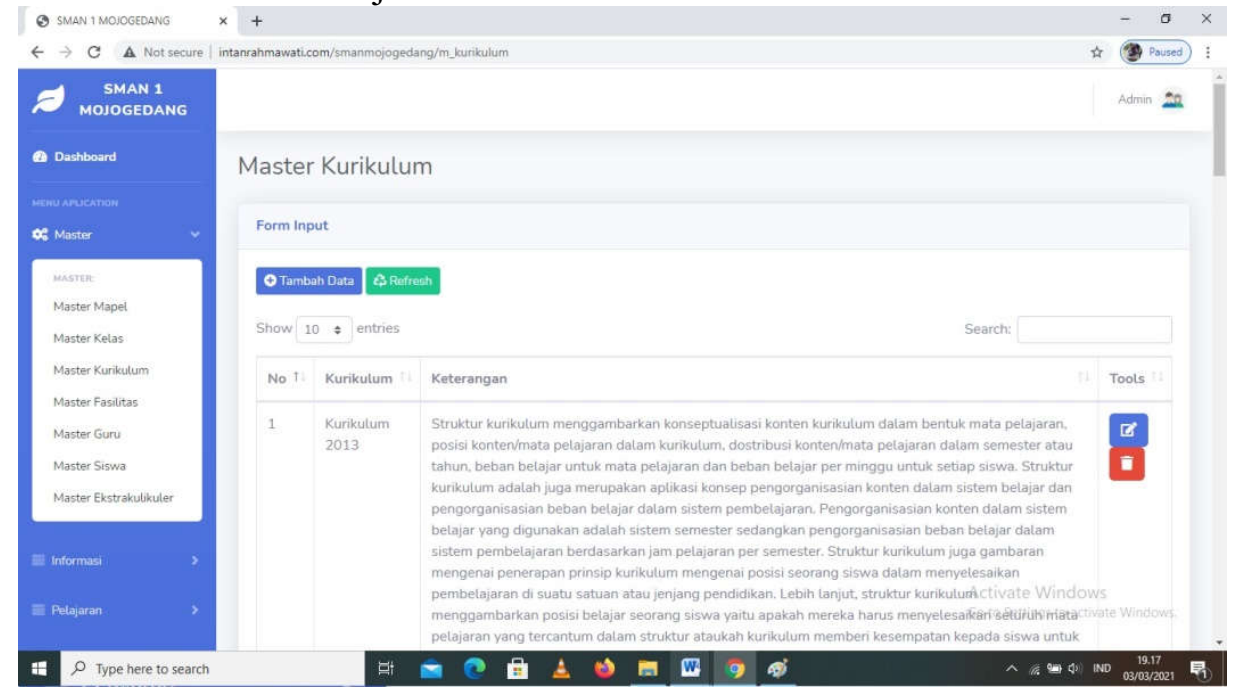

Gambar 3. Halaman master mata pelajaran

Keterangan Gambar 3 halaman Master Mata Pelajaran berfungsi untuk menginput mata pelajaran yang ada di SMA N Mojogedang. Terdapat menu "tambah Data" yang berfungsi untuk menambah data pada master mata pelajaran. Selain itu terdapat tombol edit dan hapus pada setiap mata pelajaran yang sudah tersimpan. 
d. Halaman Master Kelas

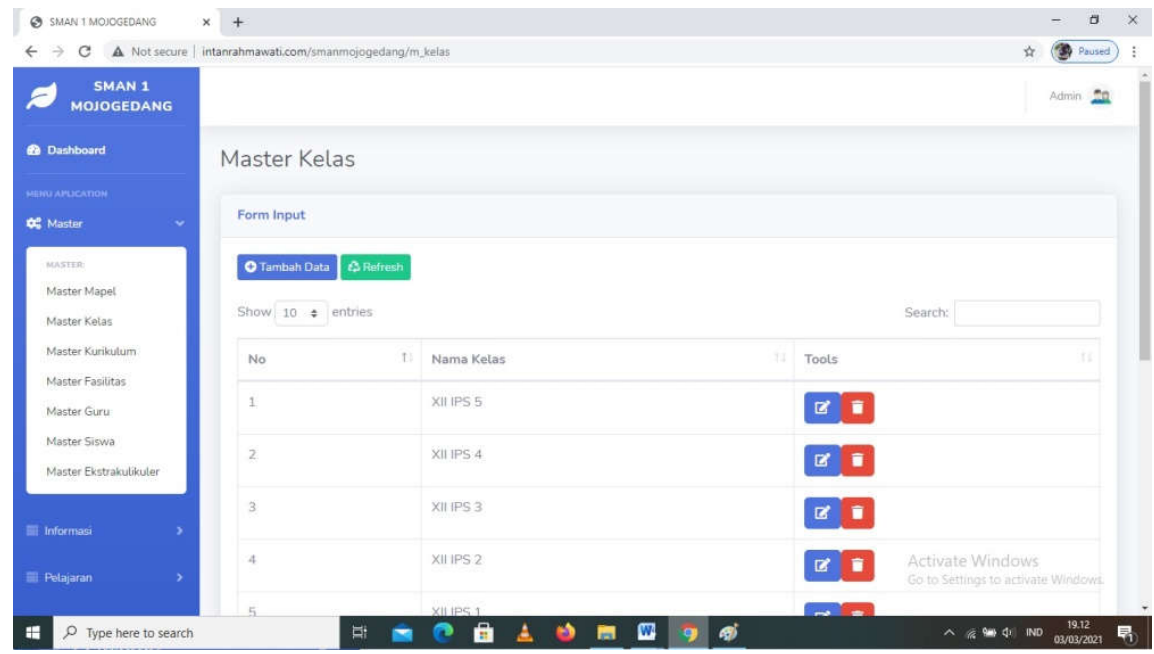

Gambar 4. Halaman master kelas

Keterangan Gambar 4 halaman Master kelas berfungsi untuk menginput informasi mengenai kelas. Pada menu ini terdapat menu tambah Data yang berfungsi menambah kelas. Selain itu terdapat tombol edit dan hapus pada setiap mata pelajaran yang sudah tersimpan.

e. Halaman Master Kurikulum

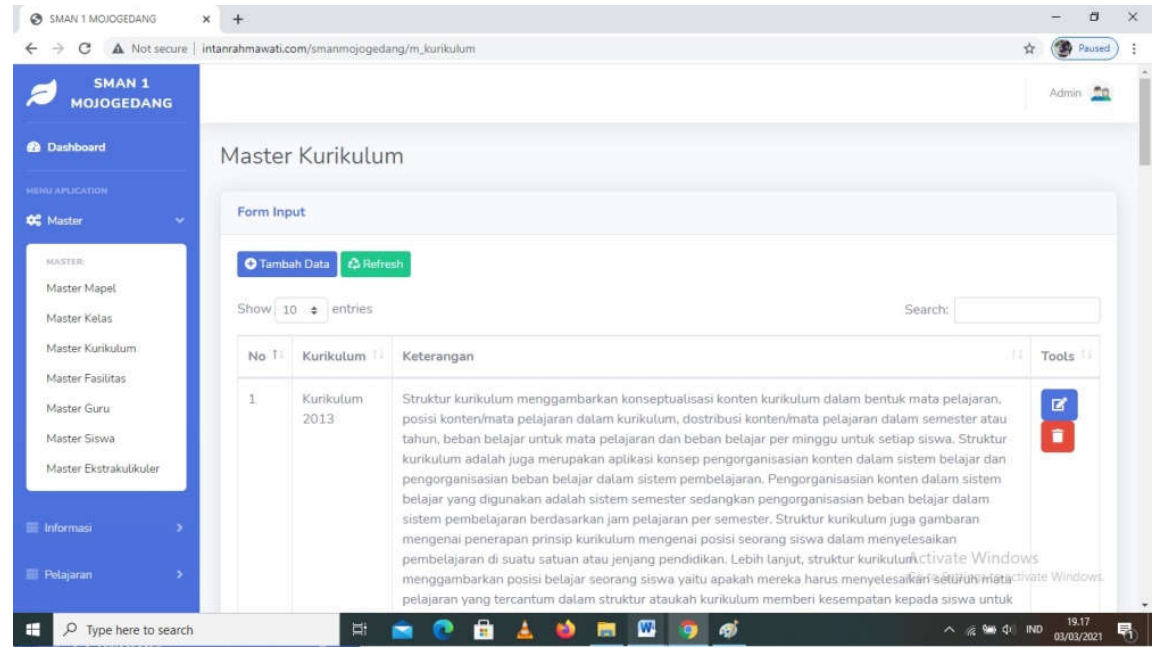

Gambar 5. Halaman master kurikulum

Keterangan Gambar 5 halaman master Kurikulum berfungsi untuk menginput informasi mengenai kurikulum di SMAN Mojogedang. Pada menu ini terdapat menu tambah Data yang berfungsi menambah informasi mengenai kurikulum serta kolom keterangan untuk informasi tambahan.

f. Halaman Master guru 


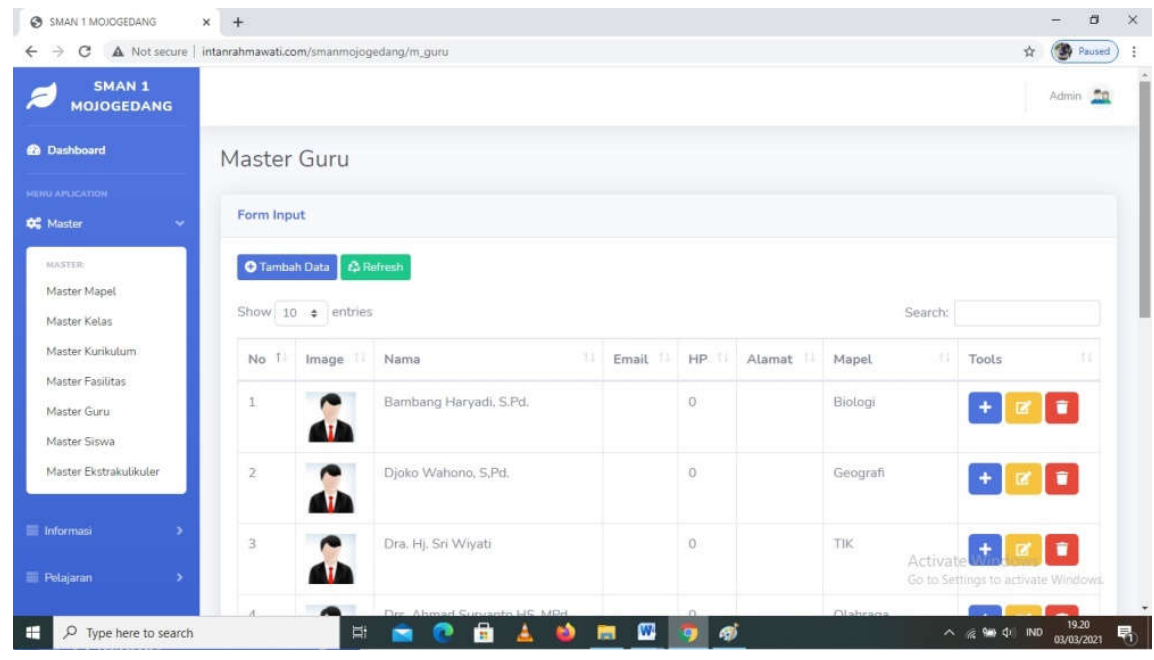

Gambar 6. Halaman master guru

Keterangan Gambar 6 halaman Master Guru berfungsi untuk menginput informasi mengenai informasi guru di SMAN Mojogedang. Pada menu ini terdapat menu tambah Data yang berfungsi menambah informasi mengenai data guru yang dilengkapi dengan informasi NIP, Password, Nama Panggilan, Nama Lengkap, Nomor HP, Email, Alamat, Mata Pelajaran dan Foto.

g. Halaman Master Siswa

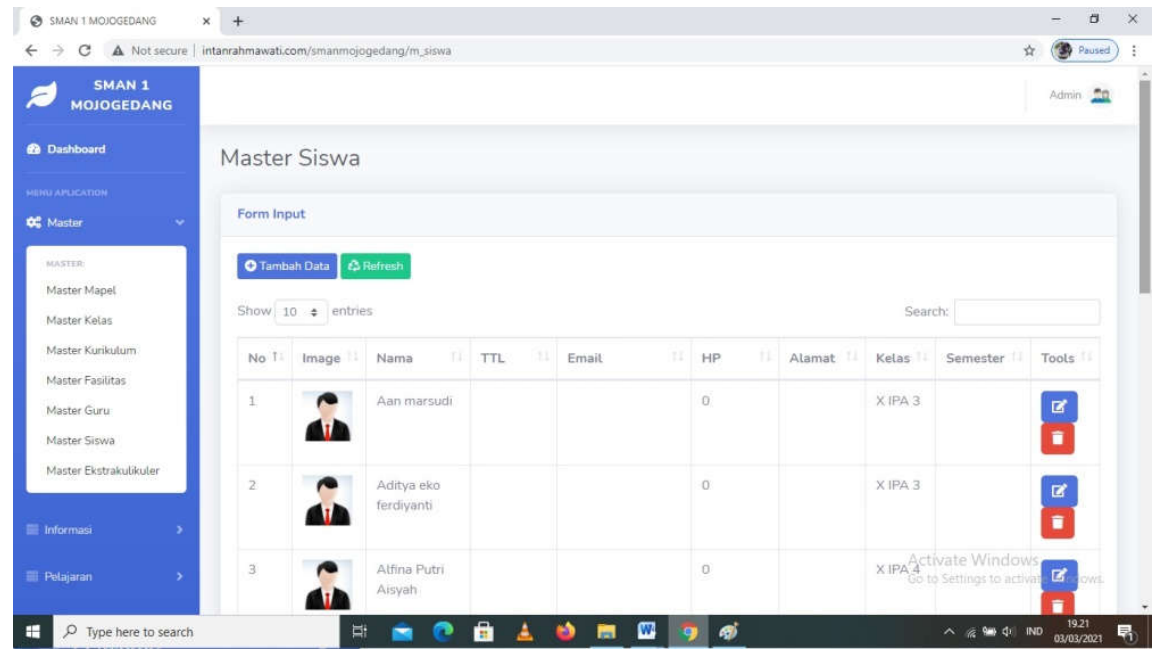

Gambar 7. Halaman master siswa

Keterangan Gambar 7 Halaman Master Siswa berfungsi untuk menginput informasi mengenai informasi siswa di SMAN Mojogedang. Pada menu ini terdapat menu tambah Data yang berfungsi menambah informasi mengenai data siswa yang dilengkapi dengan informasi NIS, Password, Nama Panggilan, Nama Lengkap, Nomor HP, Email, Alamat, Angkatan, Kelas, Semester, dan Foto.

h. Halaman Master Ekstrakulikuler 


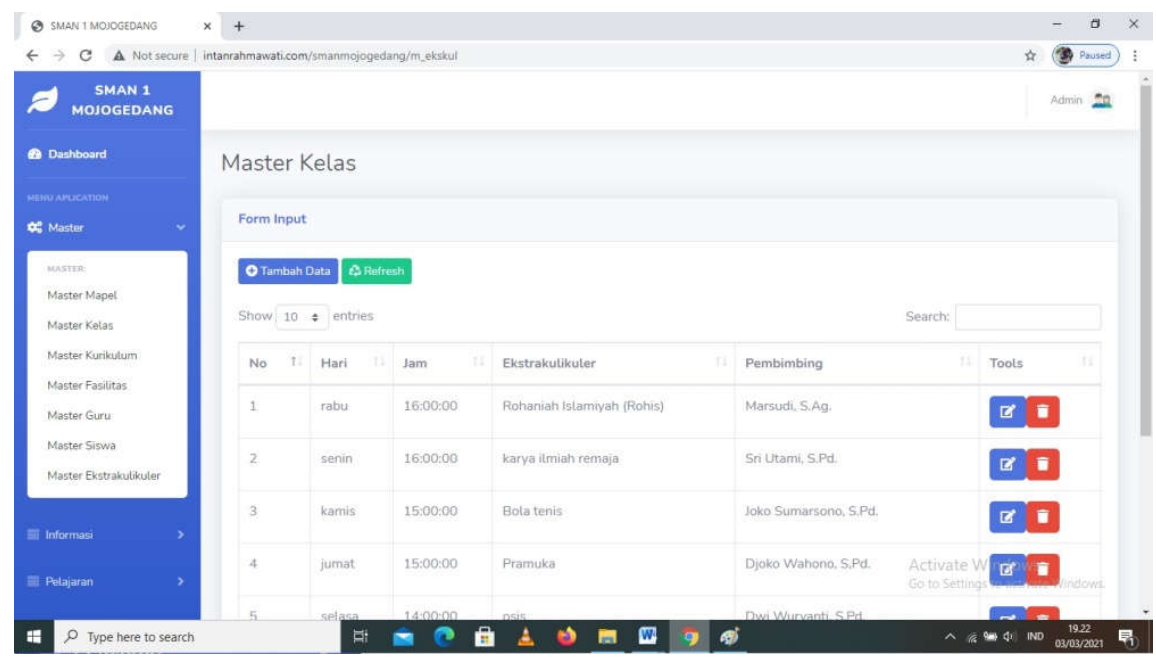

Gambar 8 Halaman master ekstrakulikuler

Keterangan Gambar 8 halaman Master Ekstrakullikuler berfungsi untuk menginput informasi mengenai informasi ekstrakulikuler di SMAN Mojogedang. Pada menu ini terdapat menu tambah Data yang berfungsi menambah informasi mengenai data ekstrakulikuler yang dilengkapi dengan informasi nama ekstrakulikuler, guru pengampu, hari dan jam ekstrakulikuler.

i. Halaman Informasi Jadwal

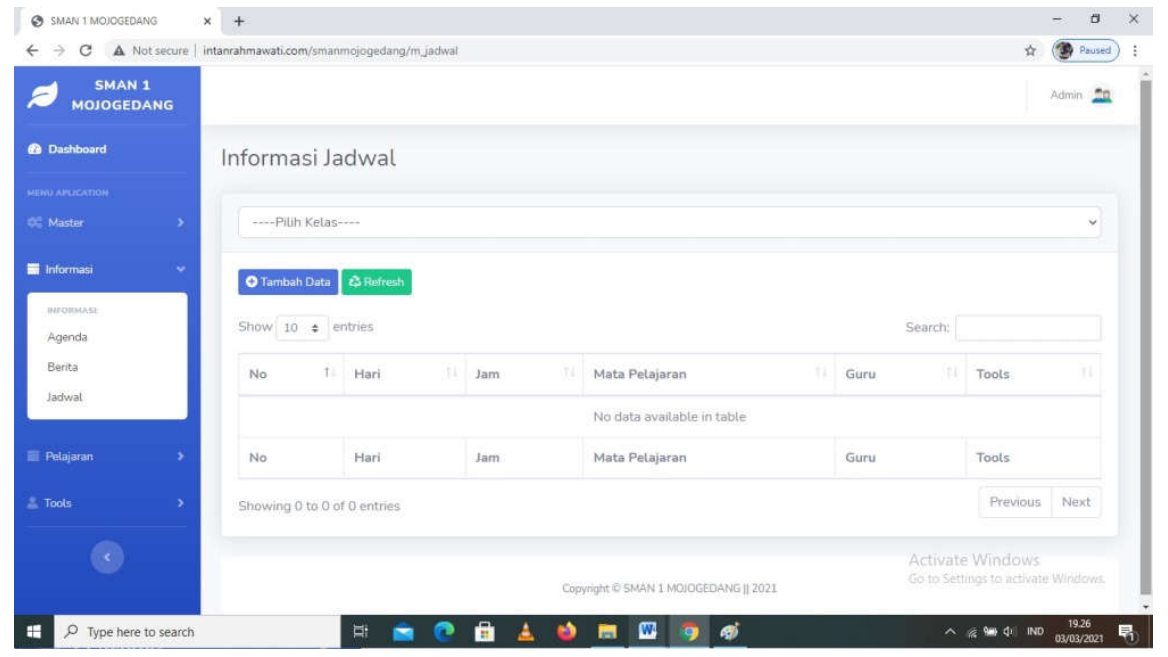

Gambar 9. Halaman informasi jadwal

Keterangan Gambar 9 halaman Informasi Jadwal berfungsi untuk menginput informasi mengenai jadwal pelajaran di SMAN Mojogedang. Pada menu ini terdapat menu tambah Data yang berfungsi menambah jadwal pelajaran yang ada di SMA N Mojogedang. Inputan pada halaman ini meliputi informasi hari, jam, mata pelajaran, dan guru. Untuk bisa memasukkan data, admin harus menginputkan kelas terlebih dahulu.

j. Halaman Materi 


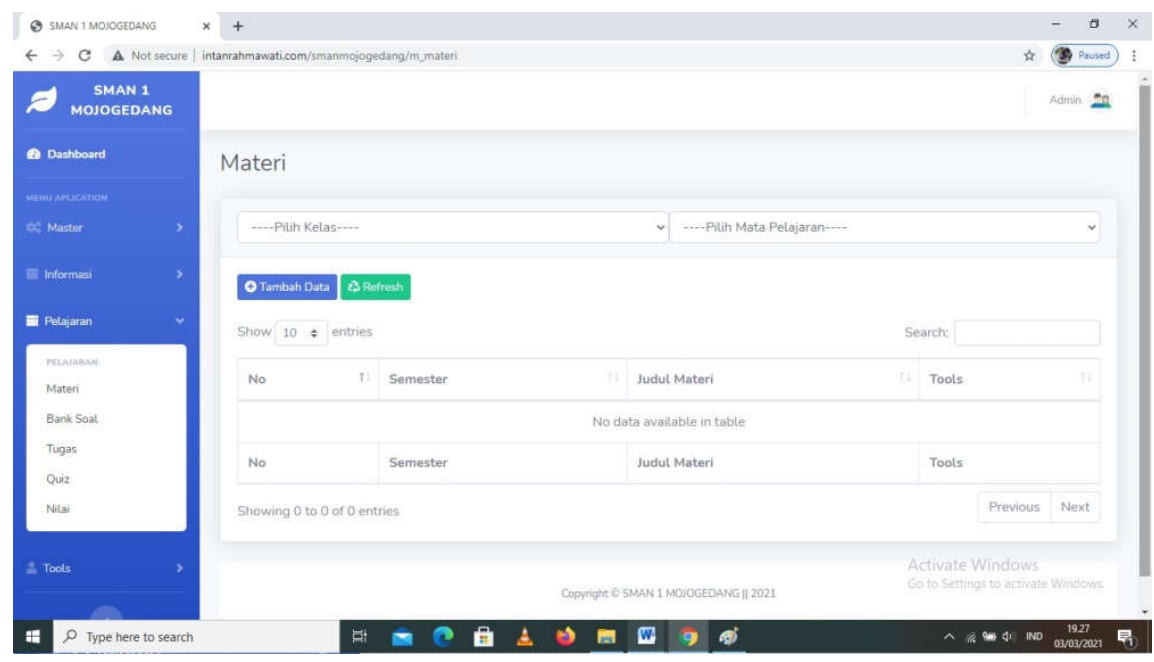

Gambar 10. Halaman materi

Keterangan Gambar 10 halaman materi berfungsi untuk menginput informasi mengenai Materi Pelajaran di SMAN Mojogedang. Pada menu ini terdapat menu tambah Data yang berfungsi menambah jadwal pelajaran yang ada di SMA N Mojogedang. Sebelum melakukan tambah data, admin harus menentukan kelas dan mata pelajaran, untuk selanjutnya mengisi form judul materi, semester dan dokumen materi.

k. Halaman Bank Soal

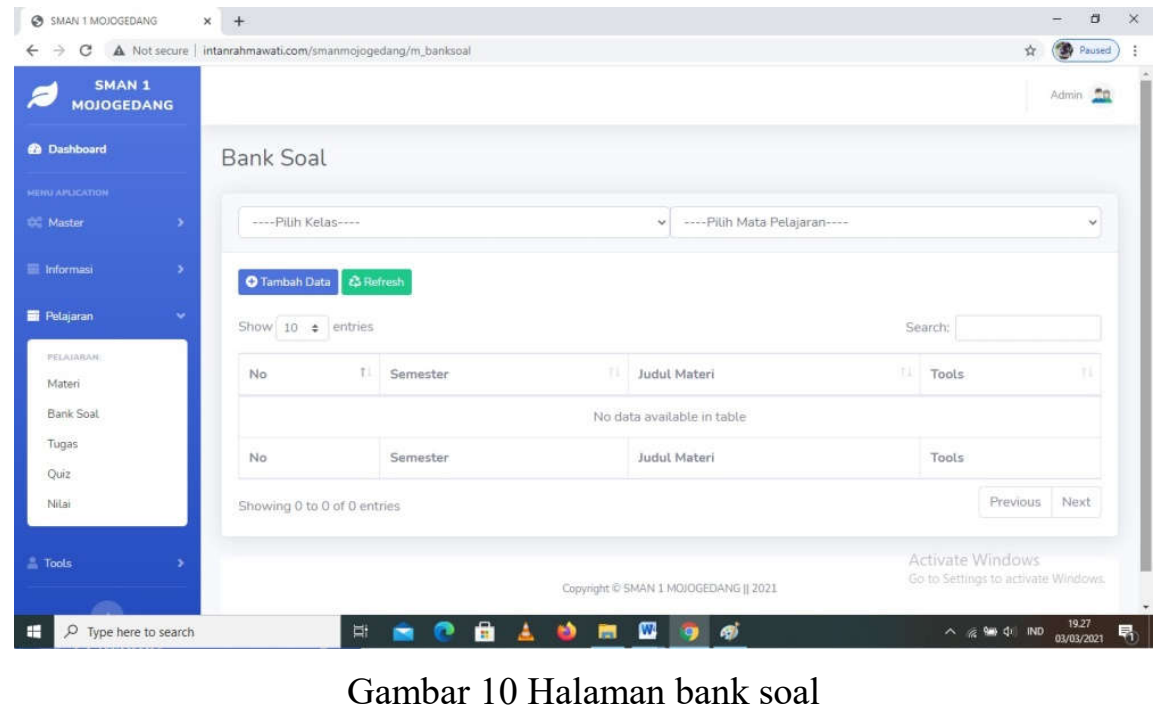

Keterangan Gambar 10 Halaman Bank Soal berfungsi untuk menginput informasi mengenai Bank Soal berbagai mata pelajaran di SMAN Mojogedang. Pada menu ini terdapat menu tambah data yang berfungsi menambah bank soal. Sebelum melakukan tambah data, admin harus menentukan kelas dan mata pelajaran, untuk selanjutnya mengisi form judul materi, semester dan dokumen bank soal.

1. Halaman Tugas 


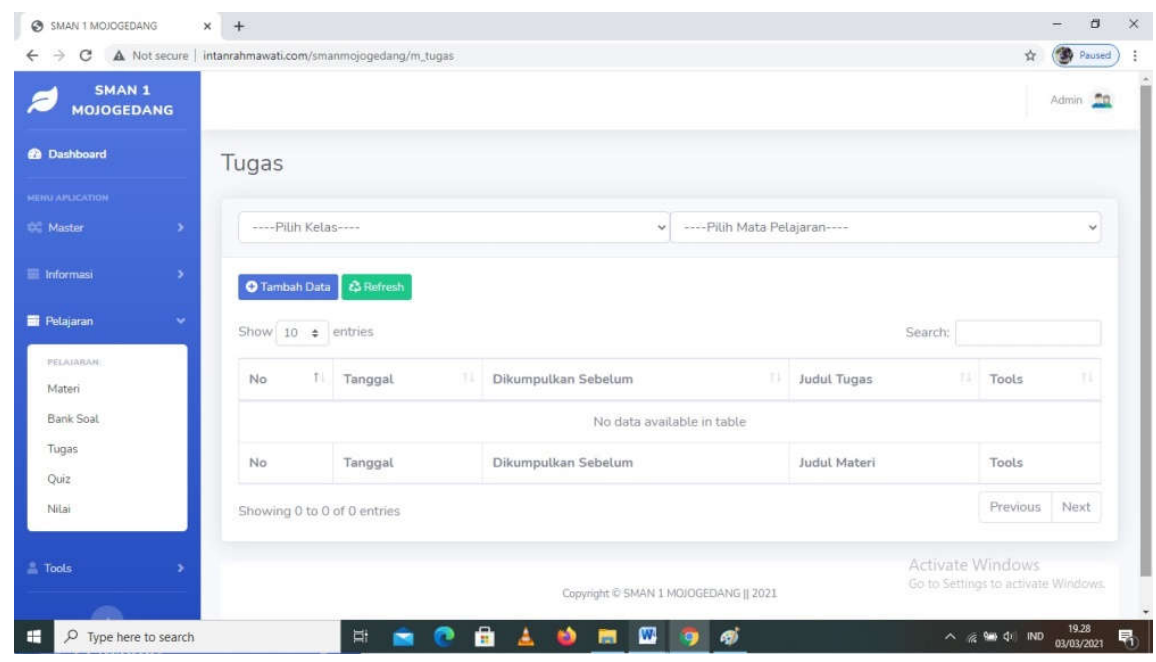

Gambar 11 Halaman bank tugas

Keterangan Gambar 11 Halaman Tugas berfungsi untuk menginput informasi mengenai Tugas berbagai mata pelajaran di SMAN Mojogedang. Pada menu ini terdapat menu tambah Data yang berfungsi menambah data tugas. Sebelum melakukan tambah data, admin harus menentukan kelas dan mata pelajaran, untuk selanjutnya mengisi form judul tugas dan dokumen tugas.

m. Halaman Nilai



Keterangan Gambar 12 Halaman Nilai berfungsi untuk menginput informasi mengenai Nilai berbagai mata pelajaran dari setiap siswa. Pada menu ini terdapat menu tambah Data yang berfungsi menambah data nilai. Sebelum melakukan tambah data, admin harus menentukan kelas terlebih dahulu, dan secara otomatis data siswa akan muncul. Setelah siswa dipilih, maka admin akan diarahkan ke halaman input nilai siswa dimana terdapat form seperti mata pelajaran, nilai kkm, nilai tugas, praktek UTS dan UAS, dan nilai keterampilan kompetensi.

\subsection{Pembahasan}

Tahap pemeliharaan dilakukan setelah tahap implementasi. Sistem baru yang berjalan digunakan sesuai dengan keperluan organisasi. Selama masa hidupnya, sistem secara periodik akan ditinjau. Perubahan dilakukan jika muncul masalah atau jika ternyata ada kebutuhan baru. 
Selanjutnya, organisasi akan menggunakan sistem yang telah diperbaiki tersebut. Pemeliharaan sistem meliputi:

a. System Back-Up

Membuat Salinan/copy untuk data-data penting yang ada pada komputer penjual maupun server kedalam backup storage.

b. System Optimization

Melakukan Defragmentasi data dan membuang sampah-sampah yang ada pada komputer, serta memperbaiki kesalahan setting sehingga komputer dapat berjalan normal.

c. System Rebuild

Membangun dan menata ulang kembali sistem yang rusak oleh faktor yang tidak disengaja, agar dapat bekerja normal kembali.

d. System Upgrade

Menambah fungsi, memperbaharui sistem yang ada sesuai dengan kebutuhan penjual, serta melakukan testing stabilitas untuk hardware dan software.

e. Training dan Pelatihan

Memberikan pengarahan dan konsultasi kepada staff sekolah sehingga staff dapat mengoperasikan komputer sesuai dengan prosedur pengoperasian komputer yang baik dan benar.

f. Update Anti Virus dan Pembersihan Virus

Melakukan update definition file anti virus sehingga anti virus yang ada dapat memproteksi komputer dari serangan virus dan juga melakukan scanning virus serta membersihkan komputer dari virus.

g. System Security

Pemasangan firewall dan sistem authentifikasi untuk pengamanan sistem dan data penting sistem informasi belajar mengajar dari orang luar yang tidak berkepentingan.

\section{KESIMPULAN}

Kesimpulan penelitian sebagai berikut metode pengumpulan data menggunakan metode observasi, wawancara pustaka dan metode waterfall. Rancangan aplikasi sistem informasi belajar mengajar di SMAN Mojogedang, telah di rancang untuk memudahkan penyebaran informasi dan proses pembelajaran dari pihak sekolah kepada siswanya. Aplikasi sistem informasi belajar mengajar di SMAN Mojogedang memiliki berbagai fitur yang memudahkan penyebaran informasi berupa profil sekolah, berita sekolah, jadwal pelajaran, jadwal ekstrakulikuler, agenda sekolah, nilai, materi pelajaran, tugas, bank soal, serta dapat melakukan chating untuk memudahkan komunikasi antara siswa dan guru. Hasil pengujian perangkat lunak pada perancangan aplikasi sistem informasi belajar mengajar di SMA N Mojogedang Berbasis Android dengan menggunakan teknik pengujian blackbox. Dimana teknik pengujian ini hanya menguji semua fungsionalitas dari Aplikasi Sistem Informasi di SMA N Mojogedang dinyatakan sesuai dengan hasil yang diharapkan. Sedangkan pembuatan alur sistem menggunakan flowchart, usecase dan tabel relasi. Metode pengembangan sistem menggunakan metode Waterfall. Software pengembangan menggunakan Android Studio sebagai development tool, bahasa pemrograman Java. Untuk pembuatan web server menggunakan bahasa pemrograman PHP, dan MySQL sebagai pengolahan database.

\section{SARAN}

Penelitian ini masih dapat dikembangkan lebih lanjut dengan beberapa usulan pengembangan sebagai berikut dengan menambahkan fitur video conference untuk lebih 
memudahkan guru dan siswa dalam pembelajaran di rumah secara real time. Saran berikutnya tampilan pada aplikasi SMA N Mojogedang masih sederhana. Untuk itu dalam pengembangan diharapkan untuk selalu memperbarui tampilan agar lebih up to date dan tidak membosankan. Aplikasi hanya terkhusus untuk pengguna Android, Untuk itu perlu dikembangkan juga untuk membuat aplikasi smartphone dengan sistem operasi IOS ataupun windows phone.

\section{DAFTAR PUSTAKA}

[1] Aditya, Rikki. 2018. Cara Menghitung Analisis Batu Bara Menggunakan VB.net dan SQL Server. Bandung : Skripsi : Politeknik Piksi Ganesha.

[2] Alfata, Hanif., 2007. Analisis dan Perancangan Sistem Informasi. Yogyakarta : Andi Offset.

[3] Anggraeni, Elisabeth Yunaeti. 2017. Pengantar Sistem Informasi. Yogyakarta : Andi Offset.

[4] Anhar. 2010. Panduan Menguasai PHP dan MySQL Secara Otodidak. Jakarta : Media Kita

[5] Annas, Affif M., Maman S, dan Aris T. 2016. Sistem Informasi Akademik SMP Negeri 1 Lasem Berbasis Android. Semarang : Universitas Diponegoro.

[6] Aprilain, Lusia V., Harry K Saputra. 2020. Belajar Cepat Metode SAW. Bandung : Kreatif Industri Nusantara.

[7] AS, Rosa., dan Shalahudin M. 2013. Rekayasa Perangkat Lunak Terstruktur dan Berorientasi Objek. Bandung : Informatika.

[8] Aziz, Abdul., dll. 2018. Bermain Android Studio Itu Mudah, Studi Kasus Pembuatan ETilang. Yogyakarta : Deepublish

[9] Enterprise, Jubille. 2016. Belajar Java, Database, dan NetBeans dari Nol. Jakarta : Elex Media Komputindo.

[10] Firly, Nadia. 2019. Android Application Development for Rookies woth Database. Jakarta : Elex Media Komputindo.

[11] Haqi, Bai. 2019. Aplikasi SPK Pemilihan Dosen Terbaik Metode Simple Addtive Wheighting (SAW) Dengan Java. Yogyakarta : Deepublisher.

[12] Hendriyani, Yeka., dan Karmilla Suryani. 2020. Pemrograman Android, Teori dan Aplikasi. Pasuruan : Kiara Media.

[13] Herlinah., dan Musliyadi. 2019. Pemrograman Aplikasi Android dengan Android Studio, Photoshop, dan Audition. Jakarta : Elex Media Komputindo.

[14] Hermawan, Stephanus. 2011. Mudah Membuat Aplikasi Android. Yogyakarta : Andi Offset

[15] Indrajani. 2015. Database Design (Case Study All in One). Jakarta :Elex Media Komputindo.

[16] Juansyah. 2015. Pembangunan Aplikasi Child Tracker Berbasis Assisted Global Positioning Dengan Platfom Android. Jurnal Ilmu Komputer dan Informatika, Vol 1, No. 1.

[17] Kusrini. 2007. Tuntunan Praktis Membangun Sistem Informasi Akuntansi dengan Visual Basic dan Microsoft SQL Server. Yogyakarta : Andi Offset

[18] Muharto., dan Arysandi Ambarita. 2016. Metode Penilitian Sistem Informasi. Yogyakarta : Deepublish

[19] Mulyanto, Agus. 2009. Sistem Informasi Konsep dan Aplikasi. Yogyakarta : Pustaka Pelajar

[20] Nuraeni, Fitri., dan Inna R. 2017. Perancangan Media Informasi Akademik Siswa Berbasis Android. Tasikmalaya : Jurnal VOI STMIK Tasikmalaya Vol. 5, No. 1.

[21] Payara, George R, dan Radius T. 2018. Penerapan Firebase Realtime Database pada Prototype Aplikasi Pemesana Makanan Berbasis Android. Bandung : Jutisi Vol. 4 No. 3. 
[22] Pressman, Roger S. 2010. Pendekatan Praktisi Rekayasa Perangkat Lunak. Yogyakarta: Andi Offset

[23] Rachmawati, Anisa., Arief LN., dan Muhhamad A. 2017. Desin Aplikasi Mobile Informasi Pemetaan Batik Solo Trans Berbasis Android Menggunakan Location Bases Service. Semarang : Jurnal Geodasi Undip Vol 6 No 2.

[24] RN, Rifka., 2017. Step By Step Lancar Membuat SOP. Depok: Huta Publisher.

[25] Romney, Marshall B., dan Steinbart. 2015. Sistem Informasi Akuntansi. Alihbahasa: Kikin Sakinah, Nur Safira dan Novita Puspita S. Jakarta : Salemba Empat.

[26] Rusmawan, Uus. 2019. Teknik Penulisan Tugas Akhir dan Skripsi Pemrograman. Jakarta : Elex Media Komputindo.

[27] Safaat, Nazaruddin. 2012. Pemrograman Aplikasi Mobile Smartphone dan Tablet PC Berbasis Android. Bandung : Informatika

[28] Santoso, Purwadi B., dan Fahmifellany. 2018. Aplikasi Mobile Nilai Mahasiswa dan Infor Kampus Berbasis Mobile. Bandung : ISU Teknologi STT Mandala Vol. 13 No. 1.

[29] Supono., dan Findandri P. 2018. Pemrograman Web dengan Menggunakan PHP dan Framework Codeigniter. Yogyakarta : Deepublish.

[30] Suryadharma., dan Triyani B. 2019. Sistem Informasi Manajemen. Ponorogo : Uwais Inspirasi Indonesia.

[31] Siyoto, Sandu., \& Sodik, Ali. 2015. Dasar Metodelogi Penelitian. Yogyakarta: Literasi Media Publishing 